REFERENCES

Adrian, E. D., and Matthews, B. H. C. (1934). Brain, 57, 355.

Bates, J. A. V. (1953). Brain, 76, 405

Bates, J. A. V. (1954). 7. Physiol. (Lond.), 123, 48P.

Bertrand, G., Blundell, J., and Musella, R. (1965). ₹. Neurosurg., 22, 333.

Brain, Sir R. (1959). Lond. Hosp. Gaz., 62, October Suppl.

Brazier, M. A. (1960). Epilepsia (Amst.), 1, 328.

Byrom, F. B. (1954). Lancet, 2, 201.

Byrom, F. B. (1968). Proc. roy. Soc. Med., 61, 605

Cushing, H. (1908). In $\mathscr{W} . W$. Keen's Surgery, vol. 3, p. 17. Philadelphia.

Cushing, H. (1909). Brain, 32, 44

Davies, P. W., and Brink, F. (1942). Fed. Proc., 1, 19.

Denny-Brown, D. (1962). Proc. roy. Soc. Med., 55, 527

Denny-Brown, $\mathrm{D}$. (1966). The Sherrington Lectures, 8 : The Cerebral Control of Movement. Liverpool.

Echlin, F. A. (1965). \%. Neurosurg., 23, 1

Ekberg, R., Cronqvist, S., and Ingvar, D. H. (1965). Acta neurol. scand., Suppl. No. 14, p. 164 .

Espagno, J., and Lazorthes, Y. (1965). Acta neurol. scand., Suppl. No. 14, p. 58.

Feindel, W., Garretson, H., Yamamato, Y. L., Perot, P., and Rumin, N. (1965). F. Neurosurg., 23, 12.

Fischer-Williams, M., and Cooper, R. A. (1963). Electroenceph. clin. Neurophysiol., 15, 568.

Florey, H. (1925). Brain, 48, 43.

Foerster, O. (1936). Brain, 59, 135

Foerster, O., and Altenburger, H. (1935). Dtsch. Z. Nervenheilk., 135 277.

Gibbs, F. A. (1933). Proc. Soc. exp. Biol. (N.Y.), 31, 141

Gibbs, F. A., Davis, H., and Lennox, W. G. (1935). Arch. Neurol. Psychiat. (Chic.), 34, 1133.

Hardesty, W. H., Roberts, B., Toole, J. F., and Royster, H. P. (1961). Surgery, 49, 251.

Holmes, G., and Sargent, P. (1915). Brit. med. f., 2, 493.

Horsley, V. (1889). Brain, i1, 102 .

Horsley, V. (1889). Brain, 11, 102. 125

Horsley, V. (1909). Brit. med. F., 2, 125.

Horsley, V., and Clarke, R. H. (1908). Brain, 31, 45.
Hurwitz, L. J. (1962). Brit. med. J., 1, 1196.

Ingvar, D. H., and Lassen, N. A. (1961). Lancet, 2, 806.

Jasper, H. H. (1964). Epilepsia (Amst.), 5, 1.

Jennett, W. B., Harper, A. M., and Gillespie, F. C. (1966). Lancet, 2, 1162 .
Katz, L. N., and Kolin, A. (1938). Amer. 7. Physiol., 122, 788.

Kety, S. S. (1965). Acta neurol. scand., Suppl. No. 14, p. 85.

Kety, S. S., and Schmidt, C. F. (1948). $\%$. clin. Invest., 27, 476

Lassen, N. A., and Ingvar, D. H. (1961). Experientia (Basel), 17, 42.

Leyton, A. S. F., and Sherrington, C. S. (1917). Quart. F. exp. Physiol., 11,135 .

Liddell, E. G. T., and Phillips, C. G. (1951). F. Physiol. (Lond.), 112, 392 .

Lierse, W., and Horstmann, E. (1965). Acta neurol. scand., Suppl. No. 14 , p. 15

Martin, J. P. (1967). The Basal Ganglia and Posture. London.

Meyer, J. S., and Denny-Brown, D. (1955). Electroenceph. clin. Neurophysiol., 7, 511 .

Meyer, J. S., Fang, H. C., and Denny-Brown, D. (1954). Arch. Neurol. Psychiat. (Chic.), 72, 296.

Morrell, F. (1960). Epilepsia (Amst.), 1, 538

Nilsson, N. J. (1965). Acta neurol. scand., Suppl. No. 14, p. 53.

Paget, S. (1919). Sir Victor Horsley: a Study of His Life and Work. London.

Penfield, W. (1933). Ann. intern. Med., 7, 303.

Penfield, W. (1937). Ass. Res. nerv. Dis. Proc., 18, 605.

Penfield, W., and Rasmussen, T. (1950). The Cerebral Cortex of Man. New York.

Phillips, C. G. (1966). In Brain and Conscious Experience, edited by J. C. Eccles, p. 389. New York.

Schmidt, C. F. (1950). The Cerebral Circulation in Health and Disease. Springfield, Illinois.

Schmidt, C. F., and Hendrix, J. P. (1937). Ass. res. nerv. Dis. Proc., 18, 229.

Shenkin, H. A., Spitz, E. B., Grant, F. C., and Kety, S. S. (1948). f. Neurosurg., 5, 466.

Spencer, W. G., and Horsley, V. (1889). Brit. med. f., 1, 457.

Spiegel, E. A., Wycis, H. T., Marks, M., and Lee, A. J. (1947). Science, $106,349$.

Symon, L. (1967). 7. Neurol. Neurosurg. Psychiat., 30, 497.

Twitchell, T. E. (1951). Brain, 74, 443.

Walker, A. E. (1957). I. Neurophysiol., 20, 435

Walker, A. E. (1961). Neurol. Med. Chir., $3,1$.

Walter, W. G., and Crow, H. J. (1964).' Electroenceph. clin. Neurophysiol., 16, 68.

Walter, W. G., and Dovey, V. J. (1946). Lancet, 1, 5.

Walshe, F. M. R. (1947). Brain, 70, 329.

Woltman, H. W., (1953). Proc. Mayo Clin., 28, 145.

\title{
Prevention of Rhesus Immunization. A Controlled Clinical Trial with a Comparatively Low Dose of Anti-D Immunoglobulin
}

\author{
C.,DUDOK DE WIT,* M.D. ; E. BORST-EILERS,* M.D. ; CH.M. v. D. WEERDT, $†$ M.D. \\ G. J. KLOOSTERMAN, $\ddagger$ M.D.
}

Brit. med. F., 1968, 4, 477-479

\begin{abstract}
Cummary : A controlled clinical trial was carried out $\checkmark$ to test the effectiveness of a comparatively low dose of anti-D immunoglobulin $(250 \mu \mathrm{g})$ in preventing rhesus immunization.

In the control group 17 out of 329 women (5\%) formed rhesus antibodies, whereas in the treated group only 3 out of 333 women $(0.9 \%)$ showed active immunization, all three of whom had an exceptionally large transplacental bleeding.
\end{abstract}

\section{Introduction}

Clinical trials carried out in Great Britain and in the United States have convincingly shown that rhesus immunization can in nearly all cases be prevented by the administration of anti-D immunoglobulin shortly after delivery of a rhesus-positive infant (Combined Study, 1966 ; Freda et al., 1967).

- Blood Transfusion Laboratory, University Hospital, Utrecht. t Central Laboratory of the Blood Transfusion Service of the Netherlands Red Cross, Amsterdam.

$\mp$ Clinic for Obstetrics and Gynaecology of the University of Amsterdam, Wilhelmina Gasthuis, Amsterdam.

Requests for reprints should be directed to C. D. W., Blood Transfusion Requests for reprints should be directed to
Laboratory, University Hospital, Catharijnesingel 101, Utrecht, NetherLaborat
bands.
Progress is also being made in other countries to introduce this kind of prophylaxis. At present, however, the widespread application is severely limited by the supply of anti-D plasma from which the immunoglobulin is prepared. For this reason it is important to determine the minimum effective dose for the prevention of rhesus immunization.

In the New York and Liverpool trials doses of approximately 5,000 and $1,000 \mu \mathrm{g}$. of anti-D immunoglobulin respectively were used (Clarke, 1967), with practically $100 \%$ ulerapeutic effectiveness. Recently Ascari et al. (1968) published the results of a trial in which a dose of $300 \mu \mathrm{g}$. had been used, with similar success.

The present study records the effect of a $250 \mu \mathrm{g}$. dose.

\section{Material and Methods}

Patient Selection.-Ten obstetrical clinics participated in the trial over a period of 12 months. The patients comprised all nun-immunized rhesus-negative women who were delivered of a rhesus-positive child, irrespective of parity or ABO compatibility. Women were randomized by treating those with odd-numbered birthdays. The immunoglobulin was administered by intramuscular injection within 24 hours after delivery. 
Anti-D Immunoglobulin.-Anti-D immunoglobulin was prepared from 20 litres of pooled plasma donated by 18 naturally immunized women who had been selected for hightitre anti-D antibodies. Details regarding the preparation and assay have been given (Dudok de Wit and Borst-Eilers, 1968). The anti-D content of the preparation was $250 \mu \mathrm{g} . / \mathrm{ml}$.

Tests for Antibody.-Heparinized blood samples were collected on three occasions: at 32-34 weeks' pregnancy, immediately after delivery, and four to six months later. The plasma was tested for rhesus antibodies by standard saline, bromelin, and antiglobulin techniques, against a red cell suspension consisting of a 1:1 mixture of $\mathrm{O} \mathrm{CDe} / \mathrm{cde}$ and $\mathrm{O} \mathrm{cDE} / \mathrm{cde}$ cells. The same test cells were used throughout the study.

Estimation of Transplacental Haemorrhage.-All blood samples obtained at 32-34 weeks' pregnancy and immediately after delivery were examined for the presence of foetal red cells. Blood was diluted 1:3 with saline, and from $0.01 \mathrm{ml}$. of this suspension a blood film was prepared. This film was treated according to the method of Kleihauer et al., (1957). Typical $\mathrm{Hb} F$ cells were counted in an area of 82.5 sq. mm. By mixing cord blood with adult blood in vitro it was found that a foetal cell score of 60 corresponded to the presence of about $1 \mathrm{ml}$. foetal blood in the maternal circulation.

\section{Results}

The trial comprised 740 rhesus-negative women with a rhesus-positive child. In eight cases rhesus antibodies (anti-D) which had not been present at 32-34 weeks' pregnancy were found in the post-delivery blood sample. For various reasons the sample at four to six months' post partum could not be obtained from 70 women. Of the remaining 662 women, 329 had previously been allotted to the control group and 333 to the treatment group. In the former there were $261 \mathrm{ABO}$ compatible babies $(79 \%)$ and 182 primiparae $(55 \%)$, whereas in the latter these figures were $272(82 \%)$ and $181(54 \%)$, respectively.

In the control group 17 women $(5 \%)$ formed anti-D, whereas among the treated women only $3(0.9 \%)$ became immunized. The difference is significant $(P<0.01)$. In Table I the incidence of immunization is correlated with the outcome of the Kleihauer test on the post-delivery blood samples. In all three women who formed rhesus antibodies despite treatment, exceptionally large transplacental haemorrhage $(50,140$, and $180 \mathrm{ml}$.) had taken place. Details of two of these cases have been published (Dudok de Wit and Borst-Eilers, 1968, Cases 1 and 4). However, none of the six cases in the treated group with moderately large bleeds (of $5,8,10,15,19$, and $25 \mathrm{ml}$. respectively) formed rhesus antibodies.

TABLE I.-Prevention of Rhesus Immunization Following Pregnancy. TABLE 1.-Prevention of Rhesus Immunization Following Pregnancy
Results of Controlled Clinical Trial with $250 \mu \mathrm{g}$. of Anti-D

\begin{tabular}{|c|c|c|c|c|c|}
\hline \multirow{2}{*}{\multicolumn{2}{|c|}{$\begin{array}{l}\text { Approximate Amount of } \\
\text { Foetal Blood in Maternal } \\
\text { Circulation after Delivery }\end{array}$}} & \multicolumn{2}{|c|}{ Not Treated } & \multicolumn{2}{|c|}{ Treated } \\
\hline & & No. & Immunized & No. & Immunized \\
\hline $\begin{array}{l}\text { None found } \\
00 \cdot 1 \mathrm{ml} \text {. } \\
0.1-1 \mathrm{ml} \text {. } \\
1-10 \mathrm{ml} \text {. } \\
10-50 \mathrm{ml} \text {. } \\
50-100 \mathrm{ml} \text {. } \\
\geqslant 100 \mathrm{ml} \text {. }\end{array}$ & 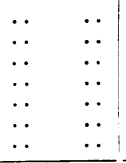 & $\begin{array}{r}171 \\
125 \\
30 \\
3 \\
0 \\
0 \\
0\end{array}$ & $\begin{array}{l}3 \\
9 \\
3 \\
2 \\
0 \\
0 \\
0\end{array}$ & $\begin{array}{r}179 \\
108 \\
37 \\
2 \\
4 \\
1 \\
2\end{array}$ & $\begin{array}{l}0 \\
0 \\
0 \\
0 \\
0 \\
1 \\
2^{*}\end{array}$ \\
\hline \multicolumn{2}{|c|}{ Total .. } & 329 & $17(5 \%)$ & 333 & $3(0.9 \%)$ \\
\hline
\end{tabular}

In addition to the 20 women who formed anti-D there was one woman in the control group who formed anti-Kell. More detailed information on these 21 cases as well as on the eight cases where anti-D antibodies appeared towards term are given in Table II. It is apparent that neither primiparae nor ABO compatible cases showed a higher immunization rate.
TABIE II.-Data on 29 Cases of Immunization by Pregnancy

\begin{tabular}{|c|c|c|c|c|c|c|c|c|}
\hline \multirow[t]{2}{*}{ Parity } & \multicolumn{2}{|c|}{ Blood Group } & \multicolumn{2}{|c|}{\begin{tabular}{|c|} 
Estimated \\
Volume of \\
Foetal Blood \\
in Maternal \\
Circulation (ml.) \\
\end{tabular}} & \multicolumn{3}{|c|}{$\begin{array}{l}\text { Titre of Immune } \\
\text { Antibody 4-6 Months' } \\
\text { Post-delivery }\end{array}$} & \multirow{2}{*}{ 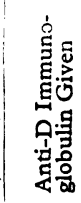 } \\
\hline & Mother & Child & $\begin{array}{c}32-34 \\
\text { Weeks' } \\
\text { Pregnant }\end{array}$ & delivery & Saline & $\begin{array}{c}\text { Brome- } \\
\text { lin }\end{array}$ & $\begin{array}{c}\text { Anti- } \\
\text { globulin }\end{array}$ & \\
\hline \multicolumn{9}{|c|}{ Rhesus-antibodies Formed before Delivery } \\
\hline $\begin{array}{c}\text { II } \\
\text { I } \\
\text { II } \\
\text { III } \\
\text { III } \\
\text { I } \\
\text { I } \\
\text { I }\end{array}$ & $\begin{array}{l}\text { A } \mathrm{Rh}^{-} \\
O \mathrm{Rh}^{-} \\
\text {A } \mathrm{Rh}^{-} \\
\text {O } \mathrm{Rh}^{-} \\
\text {A } \mathrm{Rh}^{-} \\
\text {A } \mathrm{Rh}^{-} \\
\text {O } \mathrm{Rh}^{-} \\
\text {A } \mathrm{Rh}^{-}\end{array}$ & $\begin{array}{l}\text { A } \mathbf{R h}^{+} \\
O \mathrm{Rh}^{+} \\
\text {O } \mathbf{R h}^{+} \\
\text {O } \mathbf{R h}^{+} \\
\text {A } \mathbf{R h}^{+} \\
\text {A } \mathbf{R h}^{+} \\
\text {O } \mathbf{R h}^{+} \\
\text {A } \mathbf{R h}^{+}\end{array}$ & \begin{tabular}{|c|} 
\\
0 \\
0 \\
0 \\
0 \\
0 \\
$<0.1$ \\
$<0.1$ \\
3
\end{tabular} & $\begin{array}{c}0 \\
0 \\
0 \\
0 \cdot 1 \\
0 \\
0\end{array}$ & \begin{tabular}{r|}
0 \\
0 \\
0 \\
0 \\
0 \\
256 \\
8 \\
1
\end{tabular} & $\begin{array}{r}4 \\
64 \\
16 \\
4 \\
1 \\
512 \\
32 \\
8\end{array}$ & $\begin{array}{r}2 \\
32 \\
32 \\
8 \\
1 \\
256^{*} \\
16 \\
2\end{array}$ & $\begin{array}{l}= \\
= \\
= \\
=\end{array}$ \\
\hline \multicolumn{9}{|c|}{ Rhesus-antibodies Formed after Delivery } \\
\hline $\begin{array}{r}\text { I } \\
\text { I } \\
\text { III } \\
\text { I } \\
\text { I } \\
\text { I } \\
\text { I } \\
\text { II } \\
\text { II } \\
\text { II } \\
\text { II } \\
\text { II } \\
\text { III } \\
\text { I } \\
\text { I } \\
\text { III } \\
\text { I } \\
\text { I } \\
\text { I } \\
\text { II } \\
\text { II }\end{array}$ & $\begin{array}{r}\text { O Rh- } \\
\text { O Rh- } \\
\text { B } \mathrm{Rh}^{-} \\
\mathrm{O} \mathrm{Rh}^{-} \\
\mathrm{A} \mathrm{Rh}^{-} \\
\mathrm{B} \mathrm{Rh}^{-} \\
\mathrm{A} \mathrm{Rh}^{-} \\
\mathrm{AB} \mathrm{Rh}^{-} \\
\mathrm{O} \mathrm{Rh}^{-} \\
\mathrm{B} \mathrm{Rh}^{-} \\
\mathrm{O} \mathrm{Rh}^{-} \\
\mathrm{A} \mathrm{Rh}^{-} \\
\mathrm{A} \mathrm{Rh}^{-} \\
\mathrm{A} \mathrm{Rh}^{-} \\
\mathrm{AB} \mathrm{Rh}^{-} \\
\mathrm{O} \mathrm{Rh}^{-} \\
\mathrm{A} \mathrm{Rh}^{-} \\
\mathrm{AB} \mathrm{Rh}^{-} \\
\mathrm{O} \mathrm{Rh}^{-} \\
\mathrm{A} \mathrm{Rh}^{-} \\
\mathrm{A} \mathrm{Rh}^{-}\end{array}$ & 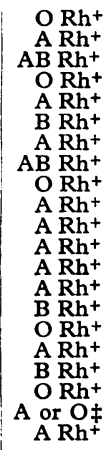 & \begin{tabular}{|l|}
0 \\
0 \\
0 \\
0 \\
$<0 \cdot 1$ \\
$<0.1$ \\
$<0 \cdot 1$ \\
$<0.1$ \\
0 \\
0 \\
$<0.1$ \\
0 \\
0 \\
$<0.1$ \\
$<0.1$ \\
0 \\
0 \\
0 \\
$<0.1$ \\
$<0.1$ \\
180 \\
\end{tabular} & \begin{tabular}{c|}
0 \\
0 \\
0 \\
$<0.1$ \\
$<0.1$ \\
$<0.1$ \\
$<0.1$ \\
$<0.1$ \\
$<0.1$ \\
$<0.1$ \\
$<0.1$ \\
$<0.1$ \\
$<0.1$ \\
0.1 \\
0.5 \\
0.9 \\
1.5 \\
7 \\
50 \\
140 \\
180
\end{tabular} & \begin{tabular}{r|}
0 \\
0 \\
0 \\
0 \\
0 \\
0 \\
16 \\
0 \\
0 \\
0 \\
0 \\
0 \\
0 \\
0 \\
4 \\
0 \\
0 \\
1 \\
0 \\
2 \\
\pm
\end{tabular} & $\begin{array}{r}4 \\
2 \\
2 \\
4 \\
2 \\
2 \\
16 \\
4 \\
2 \\
4 \\
2 \\
2 \\
\pm \\
2 \\
4 \\
4 \\
2 \\
4 \\
8 \\
8 \\
8\end{array}$ & $\begin{array}{c}0 \\
2 \\
4 \\
8^{*} \\
0 \\
16 \\
8 \\
1 \\
2 \dagger \\
2 \\
4 \\
4 \\
1 \\
2 \\
4 \\
2 \\
2 \\
32 \\
64 \\
32^{*} \\
16^{*}\end{array}$ & $\begin{array}{c}= \\
= \\
= \\
= \\
= \\
= \\
= \\
= \\
= \\
750 \mu \mathrm{g} \\
250{ }^{\mu \mathrm{g}}\end{array}$ \\
\hline
\end{tabular}

So far only four women, all of whom belonged to the treatment group, have given birth to another rhesus-positive child. In none of these cases have rhesus antibodies been found.

\section{Discussion}

The results of this trial show that rhesus immunization could largely be prevented by the administration of $250 \mu \mathrm{g}$. of anti-D immunoglobulin within 24 hours of delivery. There were, however, circumstances in which prophylaxis failed.

In the first place antibodies had appeared before delivery in eight women. This could be due to primary immunization during pregnancy or it could be a booster response following earlier sensitization by pregnancy or blood transfusion. Four of the women were multiparae, for whom the latter explanation is the more likely. The remaining four primiparae all had a negative history of pregnancies or transfusion; nevertheless, the high anti-D titre in three of these cases suggests a booster reaction rather than a primary immunization (see Table II). From our rcsults it would appear, therefore, that primary immunization during pregnancy is probably a rare occurrence. This is in agreement with the observations of Nevanlinna and Vainio (1962), who found only four examples of rhesus immunization during pregnancy in a study of more than 4,000 primiparae. A different opinion is held by Chown (1968), who estimated the incidence at $2 \%$. In order to prevent antibody formation in these cases the Winnipeg group has started the administration of anti-D during the last trimester of pregnancy in a limited number of women (Zipursky and Israels, 1967).

In the second place immunoprophylaxis failed in all three cases in which a very large transplacental haemorrhage had occurred. So far only seven cases of attempted prophylaxis after massive transplacental haemorrhage have been reported, the dose of anti-D varying from 250 to $1,000 \mu \mathrm{g}$. (Dudok de Wit and Borst-Eilers, 1968, Hughes-Jones and Mollison, 1968 ; Woodrow et al., 1968). In five of these cases active immunization occurred, suggesting that if immunosuppression can be achieved at all under these circumstances much higher doses 
of anti-D will be required. Transplacental bleeding of $50 \mathrm{ml}$. or more occurred in 3 out of 740 cases in our series; the frequency, however, of such large foetomaternal transfusions is generally supposed to be lower. Thus Schneider and Schoof (1964), in a series of 1,300 hospital deliveries, observed no transplacental bleeds of more than $12 \mathrm{ml}$. We feel, therefore, that there is no justification in trying to adjust the standard dose of anti-D to the requirement met with in the rare instances of massive transplacental bleeding. In view of the limited supply of anti-D immunoglobulin the standard dose should be the smallest dose that is effective in cases with small and moderately large bleeds. In this context it is encouraging to note that in our study none of the six women in the treated group with bleeds of 5 to $25 \mathrm{ml}$. developed rhesus antibodies.

It therefore seems reasonable to propose that further trials be undertaken to determine whether, in fact, anti- $\mathrm{D}$ immunoprophylaxis may be achieved with doses even smaller than $250 \mu \mathrm{g}$.

We are indebted to Dr. W. Huitema, Kweekschool voor Vroedvrouwen, Amsterdam; Professor J. Janssens, Academisch Ziekenhuis V.U., Amsterdam; Professor L. A. Joosse, Academisch Ziekenhuis, Groningen ; Professor G. J. Kloosterman, Wilhelmina Gasthuis, Amsterdam ; Professor J. L. Mastboom, St. Radboud Ziekenhuis, Nijmegen ; Professor W. P. Plate, Academisch Ziekenhuis, Utrecht ; Dr. H. Rottinghuis, Onze Lieve Vrouwen Gasthuis,
Amsterdam; Professor A. L. C. Schmidt, Dijkzigt Ziekenhuis, Rotterdam; Dr. J. C. Seelen, Ziekenhuis van de H. Joannes de Deo, Den Haag; Professor A. Sikkel, Academisch Ziekenhuis, Leiden; and their respective staffs for participation in the trial.

The immunoglobulin preparation was produced by $\mathrm{Dr}$. H. W. Krijnen, Central Laboratory of the Blood Transfusion Service of the Netherlands Red Cross, Amsterdam.

The anti-D content of the immunoglobulin preparation was kindly determined by Dr. N. C. Hughes-Jones, Wright-Fleming Institute of Microbiology, St. Mary's Hospital, London. All serological tests were performed by Miss Josée Matthey.

\section{REFERENCES}

Ascari, W. Q., Allen, A. E., Baker, W. J., and Pollack, W. (1968). F. Amer. med. Ass., 205, 1 .

Chown, B. (1968). Lancet, 1, 759.

Clarke, C. A. (1967). Brit. med. $\dot{f}_{\text {. }}, 4,7$.

Combined Study (1966). Brit. med. F., 2, 907.

Dudok de Wit, C., and Borst-Eilers, E. '(1968). Brit. med. F., 1, 152.

Freda, V. J., Gorman, J. G., Pollack, W., Robertson, J. G., Jennings, E. R., and Sullivan, J. F. (1967). F. Amer. med. Ass., 199, 390.

Hughes-Jones, N. C., and Mollison, P. L. (1968). Brit. med. F., 1, 150.

Kleihauer, E., Braun, H., and Betke, K. (1957). Klin. W schr., 35, 637.

Nevanlinna, H. R., and Vainio, T. (1962). Proceedings of Eighth Congress of International Society of Blood Transfusion, Tokyo 1960, edited by L. Holländer, p. 281. Basel.

Schneider, J., and Schoof, G. (1964). Zbl. Gynäk., 86, 1829.

Woodrow, J.' C., Bowley, C. C., Gilliver, B. E., and Strong, S. J. (1968), Brit. med. F., 1, 148 .

Zipursky, A., and Israels, L. G. (1967). Canad. med. Ass. 7., 97, 1245.

\title{
Significance of Rh-sensitization during Pregnancy: Its Relation to a Preventive Programme
}

\author{
JOHN C. GODEL,* M.D., F.R.C.P.(C.) ; DONALD I. BUCHANAN,* M.D., D.P.H.; JEAN M. JAROSCH,* R.T. \\ MAUREEN MCHUGH, $\dagger$ A.R.T.
}

Brit. med. F., 1968, 4, 479-482

\begin{abstract}
Cummary : A study of the incidence of $\mathbf{R h}$-sensitization $\$$ showed a $6.5 \%$ incidence of anti-D appearing for the first time during the last trimester of pregnancy. In 24 of the 29 subjects these antibodies were weak, and were found only when a sensitive technique using enzymetreated Rh-deletion test cells was employed. The remaining five, however, had high-titre antibodies, which were associated with a positive Coombs test on cord blood.

Rh-immune globulin administered at delivery resulted in disappearance of the anti-D in all but one of the subjects with weak antibody to whom it was given, suggesting that this treatment can reverse early sensitization. There was no effect when $\mathbf{R h}$-immune globulin was given to one subject with a high anti-D titre.

Since senisitization has been found to occur frequently during the last trimester of pregnancy, an antenatal schedule of prophylaxis is advocated.
\end{abstract}

\section{Introduction}

It is now generally accepted that the administration of $\mathrm{Rh}$-immune globulin to susceptible mothers at delivery may result in almost complete suppression of antibody formation in

\footnotetext{
* Hematology Research Unit, University of Alberta Hospital, Edmonton,

† Alberta.
}

the postpartum period (Brit. med. F., 1966 ; Freda, Gorman, and Pollack, 1966 ; Zipursky and Israels, 1967 ; Mollison, 1968).

Investigation into the prevention of $\mathrm{Rh}$ sensitization has been carried on in Edmonton since January 1967 as part of a co-operative study involving the western Canadian provinces (Canad. med. Ass. 7., 1967 ; Chown, 1967). Our part in the study was designed primarily to compare the effectiveness of two different doses of $\mathrm{Rh}$-immune globulin and to try to establish a minimum effective dose. However, we were also interested in trying to establish the incidence of sensitization during the last trimester of pregnancy. Our interest was stimulated by the fact that in northern Alberta from 1965 to $19673.5 \%$ of women with anti-D agglutinins found in the last trimester of pregnancy were primigravidae.

\section{Methods and Materials}

\section{Selection of Subjects}

Criteria for entry into the study were: (a) Rh-negative mother of any parity with an Rh-positive husband; $(b)$ no anti-D when first tested during pregnancy ; and (c) delivery of an $\mathrm{Rh}$-positive $\mathrm{ABO}$-compatible infant.

The following tests were done on all of the possible candidates for the study: $\mathrm{ABO}$ and $\mathrm{Rh}$ phenotype of the mother, $\mathrm{ABO}$ 